\title{
集中系モデルによる気液二相流中圧力波の解析
}

\author{
石川 諭 ${ }^{* 1}$, 近藤 孝広 ${ }^{* 2}$, 松崎 健一郎 ${ }^{* 3}$, 榎元 啓允 ${ }^{* 4}$
}

\section{Analysis of pressure wave in gas-liquid two-phase flows by concentrated mass model}

\author{
Satoshi ISHIKAWA ${ }^{* 1}$, Takahiro KONDOU ${ }^{* 2}$, Kenichiro MATSUZAKI ${ }^{* 3}$ and Hiromitsu EMOTO ${ }^{* 4}$ \\ ${ }^{*_{1},{ }_{2},{ }^{*} 4}$ Department of Mechanical Engineering, Kyushu University \\ Motooka 744, Nishi-ku, Fukuoka-shi, Fukuoka, 819-0395 Japan \\ ${ }^{* 3}$ Department of Mechanical Engineering, Kagoshima University \\ Korimoto 1-21-40, Kagoshima-shi, Kagoshima, 890-0065 Japan
}

\section{Received 24 February 2014}

\begin{abstract}
A pressure wave generated by a compressor propagates in an air-conditioner piping system and causes a noise problem. The flow condition in the air-conditioner piping system becomes often a one-component two-phase flow, and attenuation of the pressure wave in the one-component two-phase flow is larger than the two-component two-phase flow because of the effect of the mass transfer. It is also important for the safety of nuclear reactors to understand the characteristic of pressure wave problems in the one-component two-phase flow. In this paper, we propose a concentrated mass model to analyze the pressure wave problems in the one-component two-phase flow. This model consists of masses, connecting springs, connecting dampers, and nonlinear base support dampers. The connecting spring and the connecting damper are derived from the compressibility of the gas phase and the effect of the mass transfer when the phase-change occurs. And the nonlinear base support damper is derived from the pipe friction. Additionally, an experiment on an air-conditioner piping system is performed, and the experimental results are compared with the numerical result in order to confirm the validity of the model. The numerical computational results agree very well with the experimental results. Especially, the attenuation of the pressure wave generated by the phase-change is numerically reproduced. Therefore, it is concluded that the proposed model is valid for the numerical analysis of the pressure wave problem in the two-phase flow.
\end{abstract}

Key words : Method of vibration analysis, Simulation, Modeling, Vibration coupled with fluid motion, Pressure wave, Damping, Gas-liquid two-phase flow, Air conditioner

\section{1. 緒言}

空調用配管系では，圧縮機の吸入および吐出時の流動変動により発生する圧力波が配管内を伝播し，しばしば 騒音問題を引き起こす，運転条件によっては，配管内の流れは一成分気液二相流となるが，蒸発・凝縮を伴う一 成分気液二相流中の圧力波は，質量輸送の影響により減衰が大きくなることが知られている(赤川他，1986)，(藤 井，赤川，1986)．そこで，騒音対策のために一成分気液二相流を利用寸る対策が考えられる．また，一成分気液 二相流中の水撃現象の特性把握は, 原子炉における安全解析やパイプライン輸送の安全性の検討に関して重要で ある.

気液二相流中圧力波の従来の解析手法としては，スラグ流に対して液部分を質量，気相部分をばねをみなした 気液栓列モデルがあるが，減衰は考慮されていない(松井他，1979). また，連続の式，運動量の式および気体の 状態変化式に対して差分法を用いた解析なども行われている(赤川他，1982). しかしながら，一成分気液二相流

\footnotetext{
${ }^{*}$ No. 14-00104 [DOI: 10.1299/transjsme.2014dr0166]

*1 正員, 九州大学大学院工学研究院（T819-0395 福岡県福岡市西区元岡 744）

*2 正員, フェロー, 九州大学大学院工学研究院

*3 正員, 鹿児島大学大学院理工学研究科（广890-0065 鹿児島県鹿児島市郡元 1-21-40)

*4 九州大学大学院工学府 (現小松製作所)

E-mail of corresponding author: ishikawa@mech.kyushu-u.ac.jp
} 
中の圧力脈動現象に対して質量輸送の影響をも考慮した簡易的な数值解析モデルは見当たらない.

著者らは，これまで円筒管内の非線形圧力波現象に対して，流体を多自由度集中系にモデル化し，実用的な解 析手法を提案してきた(石川他，2009，2010a，2010b)．本報では，流体の圧縮性に関する非線形性は考慮せず，一 成分気液二相流中の 1 次元線形圧力波現象を対象として取り扱い, 質量, 結合ばね, 結合減衰, 非線形基礎支持 減衰から構成される多自由度集中系モデルを提案する. このモデルの要点は, 相変化に伴う質量輸送の効果を結 合ばねと結合減衰に組み込んだことである，さらに，空調機配管内の二相流圧力波の実験結果と集中系モデルに よる解析結果を比較することにより，提案モデルの妥当性を検証する.

Table 1 Nomenclature

\begin{tabular}{|c|c|c|c|}
\hline Parameter & Symbol & Parameter & Symbol \\
\hline Cross sectional area & $A$ & Mass of mass point & $m$ \\
\hline Void fraction at equilibrium & $\alpha$ & Constant of spring & $k$ \\
\hline Length of element & $l$ & Damping coefficient & $c$ \\
\hline Displacement of nodal point $i$ & $x_{i}$ & Bulk modulus of gas phase & $K_{g}$ \\
\hline Pressure at equilibrium & $p_{0}$ & Quantity of mass transfer & $\delta m_{i}$ \\
\hline Pressure in element $i$ & $p_{i}$ & Coefficient of evaporation condensation & $\xi$ \\
\hline Pressure of liquid phase & $p_{l}$ & Surface area of gas bubble & $F$ \\
\hline Variation of pressure in element $i$ & $\delta p_{i}$ & Gas constant & $R$ \\
\hline Volume of element at equilibrium & $V_{0}$ & Relaxation time of bubble flow & $\tau_{b}$ \\
\hline Volume of element $i$ & $V_{i}$ & Relaxation time of spray flow & $\tau_{d}$ \\
\hline Volume of gas phase in element $i$ & $V_{g i}$ & Angular frequency & $\omega$ \\
\hline Variation of volume of gas phase & $\delta V_{g i}$ & Time & $t$ \\
\hline Density of gas phase at equilibrium & $\rho_{g 0}$ & Head loss & $h_{l}$ \\
\hline Density of liquid phase at equilibrium & $\rho_{l 0}$ & Coefficient of pipe friction & $\lambda$ \\
\hline Variation of density of gas phase & $\delta \rho_{g i}$ & Steady flow velocity & $U$ \\
\hline Homogeneous density of two phase flow & $\rho_{m}$ & Diameter of pipe & $D$ \\
\hline Temperature of liquid phase & $T_{l}$ & Coefficient of viscosity of gas phase & $\mu_{g}$ \\
\hline Temperature of gas single phase & $T_{0}$ & Coefficient of bulk viscosity & $\mu_{c}$ \\
\hline
\end{tabular}

\section{2. 集中系モデル}

円筒管内一成分気液二相流中の圧力波現象を対象とし，気液二相流の流体に対して図 1 のような質量，線形結 合ばね, 線形結合減衰, 非線形基礎支持減衰の集中系にモデル化する. 取扱う二相流の流動様式としては, 質量 輸送の効果を表す質量輸送の緩和時間（後述）が求められている気泡流もしくは噴霧流とする. 気泡流と噴霧流 のように連続相中に分散相が細かく一様に分布している場合には，二相の混合流体を均質の単一媒体として取扱 うことができ(日本機械学会編，1989)，両流動様式で圧力波の伝播特性に本質的な違いは無い．また，定常流の 影響は小さいものとして無視する.流体に作用する力として圧力変動による力と管摩擦による力がある. 圧力変 動による力は相対変位（速度）に依存するため, 結合ばね・結合減衰で考慮し，管摩擦による力は絶対速度に依 存するため非線形基礎支持減衰で考慮する.

モデル化にあたり, 管内流体を $N$ 個の要素に等分割して, 分割点（節点）に質量を集中させる. 断面積 $A$, 各 節点の質量 $m$, 平衡状態における要素長さ $l$, 平衡状態におけるボイド率 $\alpha$ は要素ごとに設定できるが, ここで は簡単のため, 全要素で同一とする. また, 節点 $i$ の変位を $x_{i}$, 体積を $V_{i}$ とする. 各要素内で液相部と気相部に 分けて, 液相は非圧縮性, 気相は圧縮性流体とみなし, 要素 $i$ の気相部に圧力変動量 $\delta p_{i}$ を定義する. 平衡状態の 圧力を $p_{0}$ として, 要素 $i$ の気相部圧力 $p_{i}$ を次のように表す. 


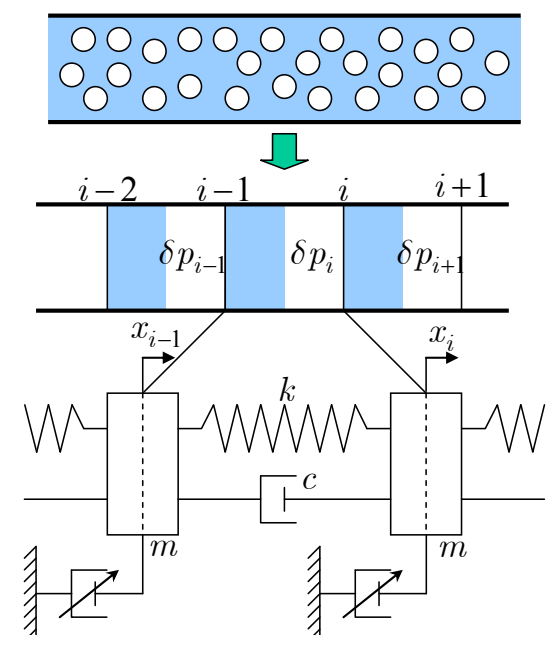

Fig. 1 The concentrated mass model is proposed to analyze the pressure wave phenomena in the one-component two-phase flow. This model consists of masses, connecting springs, connecting dampers, and nonlinear base support dampers. The fluid is divided into uniform elements. Each element is divided into the liquid phase and the gas phase. The liquid is regard as the incompressible fluid, and the gas is regard as the compressible fluid. The mass is concentrated on the nodal points. The connecting spring and the connecting damper are derived from the compressibility of the gas phase and the effect of mass transfer when the phase-change is generated.

$$
p_{i}=p_{0}+\delta p_{i}
$$

また，二相流体の質量を節点に集中させると，各節点の質量 $m$ は，

$$
m=\left\{\rho_{g 0} \alpha+\rho_{l 0}(1-\alpha)\right\} A l
$$

となる．ここで， $\rho_{g 0} ， \rho_{l 0}$ は平衡状態における気相，液相の密度である.

\section{$2 \cdot 1$ 結合ばね，結合減衰}

圧力変動量 $\delta p_{i}$ は，集中系モデルの結合ばねと結合減衰が担うものとして，

$$
\delta p_{i}=-\frac{1}{A}\left\{k\left(x_{i}-x_{i-1}\right)+c\left(\dot{x}_{i}-\dot{x}_{i-1}\right)\right\}
$$

とする．ここに， $k$ は結合ばねのばね定数， $c$ は結合減衰の減衰係数である。また，平衡状態の各要素の体積を $V_{0}(=A l)$ とし, 要素 $i$ 内の気相の体積変動量を $\delta V_{g i}$ とすると, 液相は非圧縮性と仮定しているので, 要素 $i$ の体積 $V_{i}$ は,

$$
V_{i}=V_{0}+\delta V_{g i}
$$

となる.ここで, 体積変動量 $\delta V_{g i}$ は, 質点の変位 $x_{i}$ を用いて次式のように表す.

$$
\delta V_{g i}=A\left(x_{i}-x_{i-1}\right)
$$

気相部の弾性および相変化時の質量輸送の影響を結合ばねと結合減衰で考慮する．圧縮性は気相部が担うもの とし, 圧力変動量 $\delta p_{i}$ は, 気相密度の変動量 $\delta \rho_{g i}$ を用いて,

$$
\delta p_{i}=K_{g} \frac{\delta \rho_{g i}}{\rho_{g 0}}
$$

とする．ここに， $K_{g}$ は気相の体積弾性率である.

蒸発・凝縮を伴う一成分二相流中の圧力波は，気相と液相の間で質量が移動する質量輸送の影響により二成分 
二相流と比較して減衰が大きくなる。この質量輸送の影響を結合ばねと結合滅衰でモデル化する．二相流体単位 体積，単位時間当たりの液相から気相への質量輸送量 $\delta m_{i}$ は，次式のようになる(藤井，赤川，1986).

$$
\delta m_{i}=-\frac{\xi F p_{l}}{\sqrt{2 \pi R T_{l}}}\left(1-\frac{p_{i}}{p_{l}}\right)
$$

ここに， $\xi$ は蒸発・凝縮係数， $F$ は単位体積中の気泡全表面積， $R$ はガス定数， $T_{l}$ は液相の温度， $p_{l}$ は液相の圧 力である. 液相は非圧縮性と仮定しているので, $p_{l}=p_{0}$ とすると，式(1),(7)より，

$$
\delta m_{i}=\frac{\xi F}{\sqrt{2 \pi R T_{l}}} \delta p_{i}
$$

となる. また, 平衡圧力 $p_{0}$ から圧力が変動し, 変動量 $\delta p_{i}$ が生じたとき, 蒸発・凝縮によって気相, 液相間で上 記の質量輸送が生じ, 気相部の密度が変化することで平衡圧力 $p_{0}$ に戻る. このように圧力変動が平衡圧力 $p_{0}$ に 推移するときの変化速度の指標として緩和時間があり, 圧力変動量が最初の $1 / e$ 倍になるまでの時間で定義され る.ここで， $e$ は自然対数の底である. 気泡流の場合の質量輸送による緩和時間 $\tau_{b}$ は(藤井, 赤川, 1986),

$$
\tau_{b}=-\frac{\alpha \rho_{g 0} \sqrt{2 \pi R T_{l}}}{\xi F p_{0}}
$$

となり，噴霧流の緩和時間 $\tau_{d}$ は次式のようになる(森他，1971).

$$
\tau_{d}=\tau_{b} \frac{\rho_{l 0}(1-\alpha)}{\rho_{g 0} \alpha}
$$

まず，気泡流の場合について検討する，式(8),(9)より，気泡流の場合の質量輸送量 $\delta m_{i}$ は次式となる.

$$
\delta m_{i}=-\frac{\alpha \rho_{g 0}}{\tau_{b} p_{0}} \delta p_{i}
$$

要素 $i$ 内の気相部分の質量保存を考えると, 気相部分の密度を $\rho_{g i}$, 気相の体積を $V_{g i}$ として,

$$
\frac{d}{d t}\left(\rho_{g i} V_{g i}\right)=\delta m_{i} V_{i}
$$

が成り立つ. また, 要素 $i$ 内の気相密度 $\rho_{g i}$ と気相体積 $V_{g i}$ は, 次式のように表される.

$$
\begin{aligned}
& \rho_{g i}=\rho_{g 0}+\delta \rho_{g i} \\
& V_{g i}=\alpha V_{0}+\delta V_{g i}
\end{aligned}
$$

式(4), (11), (13), (14)を式(12)に代入し, 変動量の 2 次の項を微小量として無視すると, 次式が成り立つ.

$$
\frac{d}{d t}\left(\frac{\delta \rho_{g}}{\rho_{g 0}}+\frac{\delta V_{g i}}{\alpha V_{0}}\right)=-\frac{1}{\tau_{b}} \frac{\delta p_{i}}{p_{0}}
$$

圧縮性に関する式(6)を式(15)に代入すると，

$$
\frac{d}{d t}\left(\frac{\delta p_{i}}{K_{g}}+\frac{\delta V_{g i}}{\alpha V_{0}}\right)=-\frac{1}{\tau_{b}} \frac{\delta p_{i}}{p_{0}}
$$

ここで, 要素体積が角振動数 $\omega$ で振動するものとして,

$$
\frac{\delta V_{g i}}{V_{0}}=B e^{j \omega t}
$$




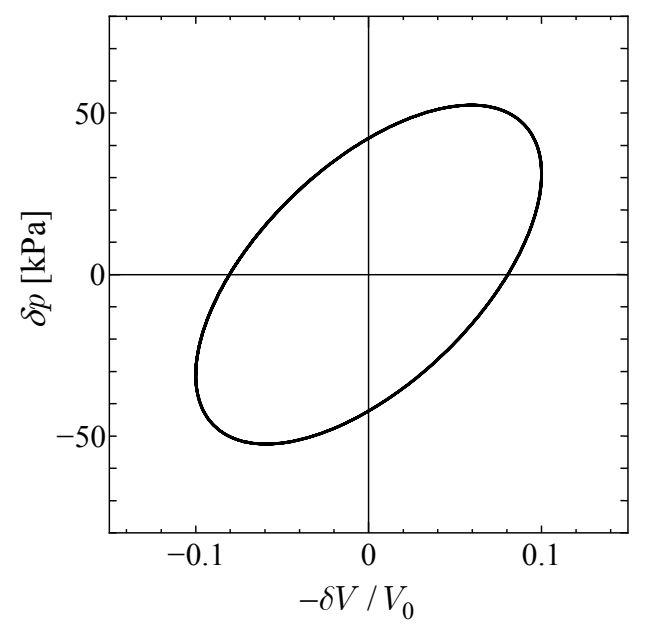

Fig. 2 This figure shows the hysteresis characteristic between the variation of pressure and the variation of volume by Eq. (19). Energy loss is generated by the mass transfer. In the concentrated mass model, the hysteresis characteristic is expressed by the connecting springs and the connecting damper. The spring constant and the damping coefficient are given by Eqs. (21) and (22).

と仮定する.ここに， $j=\sqrt{-1} ， B$ は定数である. 式(16),(17)より，

$$
\frac{d}{d t}\left(\delta p_{i}\right)+\frac{K_{g}}{\tau_{b} p_{0}} \delta p_{i}=-\frac{j \omega K_{g} B}{\alpha} e^{j \omega t}
$$

この微分方程式の特解を求めると，

$$
\delta p_{i}=-\frac{\omega^{2} \tau_{b}^{2} p_{0}^{2} K_{g}+j \omega \tau_{b} p_{0} K_{g}^{2}}{\alpha\left(\omega^{2} \tau_{b}^{2} p_{0}^{2}+K_{g}^{2}\right)} B e^{j \omega t}
$$

式(5)と式(17)より, $\left(x_{i}-x_{i-1}\right) / l=B e^{j \omega t},\left(\dot{x}_{i}-\dot{x}_{i-1}\right) / l=j \omega B e^{j \omega t}$ となるので, 式(3)より, 結合ばねと結合減衰, $B e^{j \omega t}$ を用いて圧力変動量を表すと，

$$
\delta p_{i}=-\frac{l}{A}(k+j \omega c) B e^{j \omega t}
$$

式(19)と式(20)を比較することにより，気泡流の場合の結合ばね定数 $k$ と結合減衰係数 $c$ を求めると，次式のよう になる.

$$
\begin{aligned}
& k=\frac{\omega^{2} \tau_{b}^{2} p_{0}^{2} K_{g}}{\alpha\left(\omega^{2} \tau_{b}^{2} p_{0}^{2}+K_{g}^{2}\right)} \frac{A}{l} \\
& c=\frac{\tau_{b} p_{0} K_{g}^{2}}{\alpha\left(\omega^{2} \tau_{b}^{2} p_{0}^{2}+K_{g}^{2}\right)} \frac{A}{l}
\end{aligned}
$$

次に, 噴霧流の場合には, 式(10)から求められる噴霧流の緩和時間 $\tau_{d}$ と気泡流の緩和時間 $\tau_{b}$ との間の関係

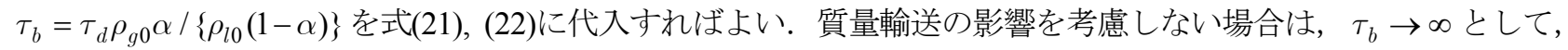
結合ばね定数 $k$ と結合減衰係数 $c$ は以下のようになる.

$$
\begin{aligned}
& k=\frac{K_{g}}{\alpha} \frac{A}{l} \\
& c=0
\end{aligned}
$$

図 2 は, 式(19)より求めた, 圧力変動量 $\delta p$ と体積変化率 $\delta V / V_{0}$ の関係を示しており, ヒステリシスループを描 
いている. これより，相変化の質量移動の影響によって，エネルギー損失が生じていることが分かる．本モデル は，このヒステリシス特性を結合ばねと結合減衰でモデル化しており，緩和時間 $\tau_{b}$ を与えることで任意条件の結 合ばね定数 $k$ と結合減衰係数 $c$ が定まる.

以上より，角振動数 $\omega$ の定常振動を仮定し，気相部分の圧縮性と質量保存を考慮することで，圧力波に対する 相変化質量輸送の効果を結合ばねと結合減衰でモデル化することができた.

\section{$2 \cdot 2$ 非線形基礎支持減衰}

$2 \cdot 1$ 節の結合減衰は, 質量輸送の効果をモデル化しているが，本節では，管摩擦による圧力損失と等価な非線 形基礎支持減衰力を導出する. 長さ $l$, 内径 $D$ の円筒管内で二相流乱流の場合に生じる損失ヘッド $h_{l}$ は定常流速 をU，管摩擦係数を $\lambda$ とすると次式で表される(Idsinga, et al., 1977).

$$
\left.\begin{array}{c}
h_{l}=\lambda \frac{l}{D} \frac{U^{2}}{2 g} \\
\lambda=\frac{0.3164}{R e^{0.25}} \\
R e=\frac{\rho_{m} D U}{\mu_{l}}
\end{array}\right\}
$$

ここに， $\mu_{l}$ は液相の粘性係数， $\rho_{m}$ は二相流を均質な混合流体とみなしたときの密度であり，次式のようになる.

$$
\rho_{m}=\rho_{g 0} \alpha+\rho_{l 0}(1-\alpha)
$$

ここで，圧力波のような非定常流においても式(25)による圧力損失が発生するものと仮定し，損失へッド中の流 速 $U$ を質点の速度 $\dot{x}_{i}$ で置き換えて，損失ヘッドを次式のように仮定する.

$$
h_{l}=\lambda \frac{l}{D} \frac{\dot{x}_{i}^{2}}{2 g}
$$

なお，レイノルズ数 Re の計算に用いる流速に関しては，定常流の流速 $U$ を使用する. 圧力損失のエネルギーと 基礎支持減衰によって消費されるエネルギーが等しいと仮定すると減衰力 $f_{i}^{b}$ は, 符合を考慮して次式で表される.

$$
f_{i}^{b}=-\lambda \frac{\rho_{0} A l}{D} \frac{\dot{x}_{i}\left|\dot{x}_{i}\right|}{2}
$$

\section{$2 \cdot 3$ 気相単相モデル}

$2 \cdot 1$ 節, $2 \cdot 2$ 節では気液二相流中の圧力波現象に対するモデルを提案したが， 3 章の実験では気相単相中の圧 力波測定も行うため, 本節では気相単相 $(\alpha=1)$ の場合の取扱いをまとめる. 各節点の質量は, 式(5)より,

$$
m=\rho_{g 0} A l
$$

気相単体の場合, 圧力変動量 $\delta p_{i}$ は結合ばねが担うものとして, 次式を仮定する.

$$
\delta p_{i}=-\frac{k}{A}\left(x_{i}-x_{i-1}\right)
$$

このとき, ばね定数 $k$ は気相の体積弾性率 $K_{g}$ を用いて,

$$
k=\frac{K_{g} A}{l}
$$

となる，結合減衰係数は，気相流体にかかる法線応力を考慮して，次式のようになる(石川他，2009). 


$$
c=\frac{4 \mu_{c} A}{3 l}
$$

ここに， $\mu_{c}$ は気相の体積粘性係数である. 非線形基礎支持減衰力に関しては, 式(28)と同様に取り扱うが，式(25) のレイノルズ数 Re は, 気相の密度 $\rho_{g 0}$ と気相の粘性係数 $\mu_{g}$ を用いて, 次式のように取り扱う.

$$
R e=\frac{\rho_{g 0} D U}{\mu_{g}}
$$

なお, 式(27)の損失ヘッドに関しては，3 章の気相単相の実験結果と解析結果の比較検討の結果，損失ヘッド中の 流速 $U$ を質点の速度 $\dot{x}_{i}$ で置き換えたものが最もよく一致したので, 流速 $U$ を速度 $\dot{x}_{i}$ で置き換える仮定をおいた.

\section{$2 \cdot 4$ 音速とボイド率の関係}

実験においてボイド率を直接測定することは難しいため, 測定した音速からボイド率を算出する.そのために,

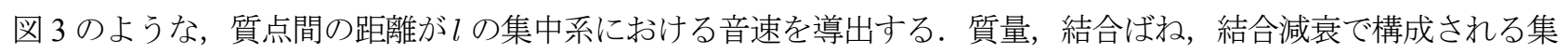
中系を連続体近似し, 縦波が集中系を伝播するときの音速を求める. 集中系において, 質点 $i$ の運動方程式は,

$$
m \ddot{x}_{i}=k\left(x_{i+1}-2 x_{i}+x_{i-1}\right)+c\left(\dot{x}_{i+1}-2 \dot{x}_{i}+\dot{x}_{i-1}\right)
$$

この式の両辺を $l^{2}$ で割ると，

$$
\frac{m \ddot{x}_{i}}{l^{2}}=\frac{k\left(x_{i+1}-2 x_{i}+x_{i-1}\right)}{l^{2}}+\frac{c\left(\dot{x}_{i+1}-2 \dot{x}_{i}+\dot{x}_{i-1}\right)}{l^{2}}
$$

ここで，質点間の差分を考えて，

$$
\frac{\partial^{2} x}{\partial \xi^{2}}=\frac{x_{i+1}-2 x_{i}+x_{i-1}}{l^{2}}
$$

とすると，式(35)は，次式のようになる.

$$
\frac{\partial^{2} x}{\partial t^{2}}=\frac{l^{2}}{m}\left(k \frac{\partial^{2} x}{\partial \xi^{2}}+c \frac{\partial^{3} x}{\partial \xi^{2} \partial t}\right)
$$

複素波数を $\kappa$ として，集中系内を伝播する進行波を次式のように仮定する.

$$
x=b \exp \{j(\omega t-\kappa \tilde{\xi})\}
$$

ここで，bは任意定数， $\tilde{\xi}$ は進行方向の位置である. 式(38)を式(37)に代入し， $\kappa$ に関して整理すると，

$$
\begin{aligned}
& \kappa=\kappa^{\prime}-j \kappa^{\prime \prime} \\
& \left.\kappa^{\prime}=\frac{\omega}{l} \sqrt{\frac{m\left(\sqrt{k^{2}+c^{2} \omega^{2}}+k\right)}{2\left(k^{2}+c^{2} \omega^{2}\right)}}, \kappa^{\prime \prime}=\frac{\omega}{l} \sqrt{\frac{m\left(\sqrt{k^{2}+c^{2} \omega^{2}}-k\right)}{2\left(k^{2}+c^{2} \omega^{2}\right)}}\right\}
\end{aligned}
$$

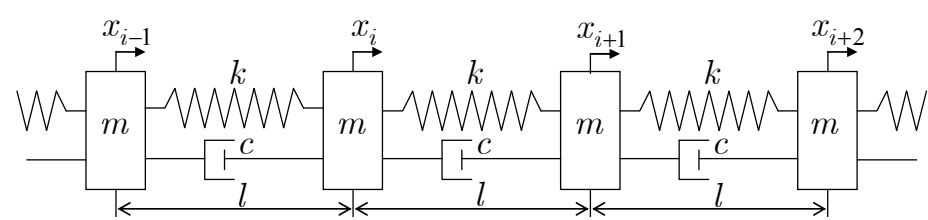

Fig. 3 A propagation speed of wave in this spring-mass-damper system is derived to determine the void fraction in the experiment from the sound speed in the two-phase flow. The spring-mass system is approximated by a continuum, and we derive a complex wave number. The propagation speed in the spring-mass system becomes Eq. (41). 


$$
\begin{aligned}
\kappa=\kappa^{\prime}-j \kappa^{\prime \prime} \text { を式(38)に代入すると, } & \\
& x=b \exp \left\{j\left(\omega t-\kappa^{\prime} \tilde{\xi}\right)\right\} \cdot \exp \left(-\kappa^{\prime \prime} \tilde{\xi}\right)
\end{aligned}
$$

となる。ここで, $\exp \left\{j\left(\omega t-\kappa^{\prime} \tilde{\xi}\right)\right\}$ は進行波の伝播を, $\exp \left(-\kappa^{\prime \prime} \tilde{\xi}\right)$ は距離減衰を表している。これから，音速 $a$ は 次式のようになる.

$$
a=\frac{\omega}{\kappa^{\prime}}=l \sqrt{\frac{2\left(k^{2}+c^{2} \omega^{2}\right)}{m\left(\sqrt{k^{2}+c^{2} \omega^{2}}+k\right)}}
$$

式(41)の $m, k, c$ は式(2), (21), (22)よりボイド率 $\alpha$ と緩和時間 $\tau_{b}$ の関数であり, 音速 $a$ も $\alpha, \tau_{b}$ の関数となる. 実 験では, 音速 $a$ を測定し, 式(41)よりボイド率 $\alpha$ と緩和時間 $\tau_{b}$ を数值的に算出する. 具体的な算出手順は 3 章で 述べる.

なお，相変化が無い場合の二相流中の音速は，式(2), (23), (24), (41)より次のように表される.

$$
a=l \sqrt{\frac{k}{m}}=\sqrt{\frac{K_{g}}{\alpha\left\{\rho_{g 0} \alpha+\rho_{l 0}(1-\alpha)\right\}}}
$$

\section{3. 空調機配管系への適用}

\section{$3 \cdot 1$ 実験装置}

2 章で提案した集中系モデルの妥当性を確認するために空調配管内の二相流圧力波の実駼結果と集中系モデル による解析結果を比較する. 藤井ら(藤井, 赤川, 1986)は, フロンR113 における水撃現象の減衰に関して, 緩和 時間 $\tau_{b}$ で整理できることを示しており，緩和時間による減衰を考慮した集中系モデルも空調機配管内の圧力波現 象（冷媒はフロン R410A）に適用できるものと考える. 実験装置を図 4 に示す. 空調用室内機, 室外機にはダイ キン製エアコン F22LTES-W を使用したが，実験の都合上四路切換え弁を取り外して冷房運転しか行えないよう に改造している．通常の冷房運転では，圧縮機で圧縮されたガスは，室外機内の熱交換器，膨張弁を通った後， 室内機へ二相流として流れ, 室内機内の熱交換器で蒸発し, 気相単相流として室外機へ戻り, 圧縮機へ吸入され る. 暖房運転では，逆向きの流れとなる．本実験では冷房運転を行い，赤破線で示した室内機から室外機までの 区間の流れが気相単相流の場合と気液二相流の場合に対して，圧縮機吸入によって生じる圧力波を(1)，(2)，(3)の 位置 (気相単相試験は(1), (3)のみ) に取り付けた変動圧センサにより測定する. 気相単相流の場合は弁 2 を閉じ, 弁 3 を開けて室内機に流体を通過させ, 気液二相流の場合は, 弁 2 を開け, 弁 3 を閉じて室内機をバイパスさせ て実験を行う.

吸入管には変動圧センサ(1)，(2)，(3)，平均圧センサ，温度センサを取り付けている. 変動圧センサ(1)，(2には Kistler 製 603B，(3) Kistler 製 601A，平均圧センサはキーエンス製 AP-15S を用いた。平均圧センサで計測した 圧力を平衡圧力 $p_{0}$, 変動圧センサの測定值を $\delta p$ とする. また, 気相単相流実験の場合のみ, 室内機近傍に $400 \mathrm{cc}$ の容器（Swagelok 製 304L-HDF4-400）を設置し，容器から室内機側の圧力波振幅を小さくして，室内機側からの 圧力波の反射の影響を小さくしている. 圧縮機の土縮機構は図 5(a)のような摇動ピストン式であり, シリンダ吸 入時の流速変動により配管内に圧力波が伝播する. 圧縮機から発生する圧力波を直接伝播させるため, 四路切換 弁とアキュームレータは取り外している. 四路切換弁は冷房時と暖房時の冷媒の流れを切り替える弁であり, ア キュームレータは液圧縮を防ぐために圧縮機吸入側に取り付ける容器である.

圧縮機の回転数を変化させて実験を行った. 表 2 に気相単相流の実験条件, 表 3 に気液二相流の実験条件を示 す.ここに， $\Omega$ はピストン回転の角速度を表す. 音速 $a$ は, 変動圧センサ(1), (3)で測定した圧力変動波形の位相 差から計算する，ちなみに，音速 $a$ は 54rps で最小になっている。これは，本実験装置が市販品を改造したもの であり，圧縮機回転数は指令できるものの電子膨張弁の開度を指令することができない，これより，圧縮機回転 数の変化とは独立に電子膨張弁の開度が勝手に変化するため, 圧縮機回転数の変化に伴って音速 $a$ が変化せず, 音速 $a$ は 54rps で最小になるものと考えられる. 


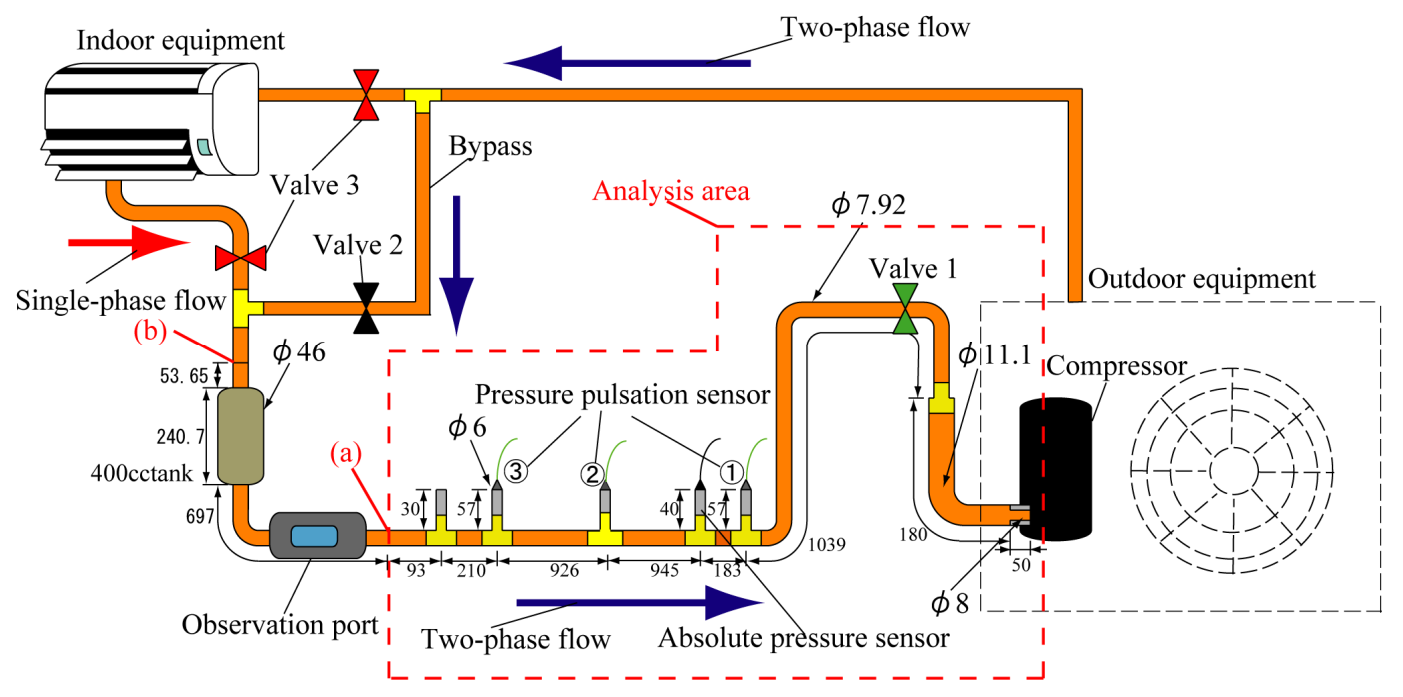

Fig. 4 An experiment on an air-conditioner piping system is performed to confirm the validity of the proposed model. For the experimental setup, an air-conditioner is modified. The accumulator is removed. Three pressure pulsation sensors are installed in the suction pipe of the compressor. To make two-phase flow in the suction pipe, the flow is bypassed the indoor equipment.

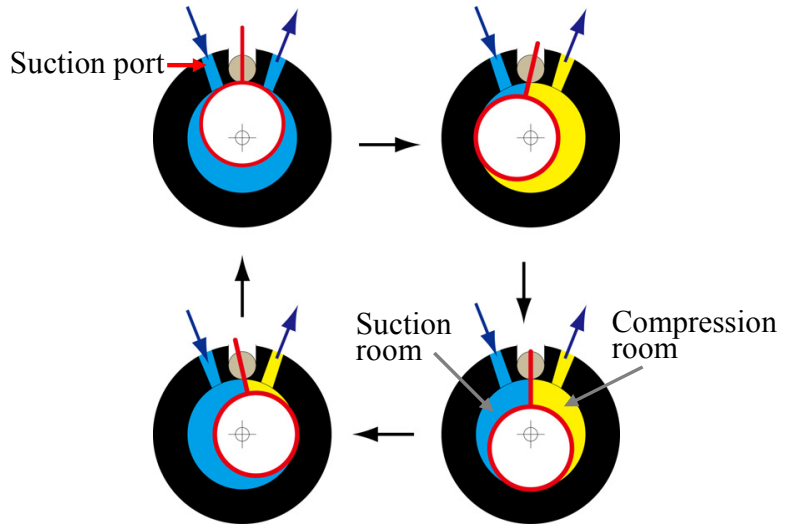

(a) Compression mechanism

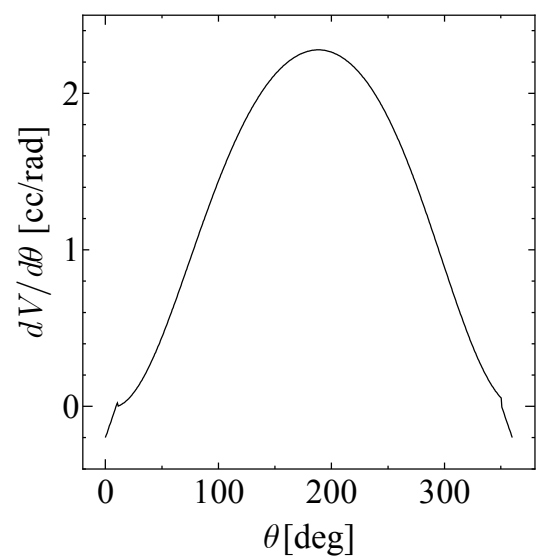

(b) Rate of volume change

Fig. 5 The compression mechanism in the compressor is swing type as shown in the left side figure. As the piston swings, the fluid is sucked in the suction room. The velocity boundary condition at the suction port is given by the rate of volume change in the suction room, as shown in the right side picture. The velocity at the suction port is given by Eq. (43).

\section{$3 \cdot 2$ 解析方法}

2 章で提案した集中系モデルを用いて，数值積分による解析を行う。二相流の場合は，図 4 の赤破線で示す圧 縮機吸入口から(a)までを解析範囲とし，気相単相流の場合は，圧縮機吸入口から(b)までとする．400cc 容器は端 部に絞りがあるものの，簡単のため同じ容積になるように内径 $46 \mathrm{~mm} ，$ 長さ $240.7 \mathrm{~mm}$ の直管として取扱う．圧力 センサ部の分岐管も解析モデルに含め, 分岐部や 400cc 容器両端部などの断面積変化部の取扱いは既報(石川他, 2010a, 2010b) と同様とする. 数值積分にはルンゲ・クッタ法を用い，時間刻みは圧縮機の回転数に応じて変化さ せ, 二相流の場合は 1 周期を 20000 分割, 単相流の場合は 1 周期を 8000 分割している.解析条件を表 2,3 に示寸. 緩和時間とボイド率に関しては，变動圧センサ(1), (3)で測定した圧力変動波形の位相差から音速 $a$ を計算し, 緩 和時間 $\tau_{d}$ を適当に仮定し，式(41)から反復計算により数值的にボイド率 $\alpha$ を算出している．そして，緩和時間 $\tau_{d}$ を変化させてボイド率 $\alpha$ を算出しながら数值解析を行い, 解析結果と実験結果が一致する緩和時間 $\tau_{d}$ を決定する. ボイド率は 0.96〜0.98 の值であり，流動様式は噴霧流と考えられ，噴霧流の緩和時間は， $\tau_{d}=4.0[\mathrm{~ms}]$ とする. 
Table 2 Parameter values (Single-phase flow)

\begin{tabular}{|c|c|c|c|c|c|c|c|}
\hline & $\Omega / 2 \pi[\mathrm{rps}]$ & $T_{0}\left[{ }^{\circ} \mathrm{C}\right]$ & $p_{0}[\mathrm{MPa}]$ & $\rho_{g 0}\left[\mathrm{~kg} / \mathrm{m}^{3}\right]$ & $K_{g}[\mathrm{MPa}]$ & $\mu_{g}[\mathrm{~Pa} \cdot \mathrm{s}]$ & $\mu_{c}[\mathrm{~Pa} \cdot \mathrm{s}]$ \\
\hline (i) & 16 & 10.1 & 1.05 & 40.1 & 1.14 & $1.28 \times 10^{-5}$ & 1.0 \\
\hline (ii) & 22 & 7.3 & 0.92 & 34.6 & 1.01 & $1.26 \times 10^{-5}$ & 1.0 \\
\hline (iii) & 28 & 8.9 & 0.88 & 32.4 & 0.97 & $1.27 \times 10^{-5}$ & 1.0 \\
\hline (iv) & 34 & 8.9 & 0.87 & 32.0 & 0.96 & $1.27 \times 10^{-5}$ & 1.0 \\
\hline
\end{tabular}

Table 3 Parameter values (Two-phase flow)

\begin{tabular}{|c|c|c|c|c|c|c|c|c|}
\hline & $\Omega / 2 \pi[\mathrm{rps}]$ & $p_{0}[\mathrm{MPa}]$ & $a[\mathrm{~m} / \mathrm{s}]$ & $\alpha$ & $K_{g}[\mathrm{MPa}]$ & $\rho_{g 0}\left[\mathrm{~kg} / \mathrm{m}^{3}\right]$ & $\rho_{l 0}\left[\mathrm{~kg} / \mathrm{m}^{3}\right]$ & $\tau_{d}[\mathrm{~ms}]$ \\
\hline (I) & 32 & 0.78 & 110.7 & 0.9755 & 0.86 & 29.9 & 1173 & 4.0 \\
\hline (II) & 38 & 0.78 & 110.7 & 0.9758 & 0.86 & 29.9 & 1173 & 4.0 \\
\hline (III) & 40 & 0.77 & 105.2 & 0.9725 & 0.85 & 29.5 & 1175 & 4.0 \\
\hline (IV) & 44 & 0.75 & 105.0 & 0.9720 & 0.83 & 28.7 & 1178 & 4.0 \\
\hline (V) & 54 & 0.77 & 76.7 & 0.9622 & 0.85 & 29.5 & 1175 & 4.0 \\
\hline (VI) & 76 & 0.56 & 123.5 & 0.9848 & 0.63 & 21.5 & 1211 & 4.0 \\
\hline (VII) & 90 & 0.54 & 131.0 & 0.9881 & 0.61 & 20.7 & 1215 & 4.0 \\
\hline
\end{tabular}

気相単相では，実験で計測した温度 $T_{0}$ ，圧力 $p_{0}$ から，解析パラメータ $\rho_{g 0} ， K_{g} ， \mu_{g}$ を， National Institute of Standard and Technology 製の REFPROP を使用して求めている. 二相流の場合は，飽和圧力を $p_{0}$ とたときの飽 和ガス, 飽和液の物性值 $K_{g}, \rho_{g 0}, \rho_{l 0}$ をREFPROPより算出している. 圧縮機吸入部の境界条件としては, 図 5(b)に示すシリンダ吸入室容積の変化率 $d V / d \theta$ を用いて, 次式に示す吸入口の流速変動 $d v_{0}$ を与え, 速度境界条 件とする.

$$
d v_{0}=-\frac{\Omega}{A_{0}} \frac{d V}{d \theta}
$$

ここで， $A_{0}$ は吸入口の断面積である. なお， $d V / d \theta$ の計算には，図 5(b)の容積変化率の波形を 30 次までのフー リエ級数で近似した関数を用いた. 解析範囲の終端は無反射端とし, 次式の減衰を終端の質点 $N$ 取り付ける.

$$
c_{t}=\rho_{m} a A_{N}
$$

ここで， $A_{N}$ は終端の断面積である。

\section{$3 \cdot 3$ 気相単相流の実験結果および解析結果}

図 6 に気相単相の実験結果と解析結果の比較を示す。センサ(1)，(3における圧力変動の時系列波形であり，黒 線が実験結果，赤線が解析結果を示す．波形，振幅とも実験結果と解析結果が回転数ごとによく一致しており， 気相単相のモデルが妥当であることが分かる. 気相単相の場合, センサ(1)と(3)の圧力振幅を比較してみると，圧 縮機から遠い(3)の位置で振幅が明確に減衰している様子はない，条件(iii)（28rps）のとき，センサ(3において特 に振幅が大きくなっている. 条件(iii)のときの解析による圧力振幅の分布を図 7 に示しているが, 圧縮機入口を固 定端, $400 \mathrm{cc}$ 容器の端を自由端とする 2 次モードの共振が発生していることが分かる.

\section{$3 \cdot 4$ 気液二相流の実験結果および解析結果}

困 8 は，配管内流れを気液二相流にした場合の，センサ(1)，(2)，(3における圧力変動の時系列波形を示してい る. 黒線の実験結果と赤線の解析結果を比較すると，条件(I), (III)の実験結果は流体の非線形性の影響で波形が若 干鋸歯状になっているが，解析モデルでは圧縮性に関する非線形性を考慮していないため，その現象は再現でき ていない. しかしながら，センサ(1)，(2)，(3)の順に振幅が小さくなり，圧力波が発生する圧縮機から離れるほど 振幅が減衰して現象を, 集中系モデルによる解析結果はよく再現できている．また，条件(IV)（54rps）における 


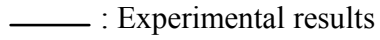

Sensor (1)

(i)

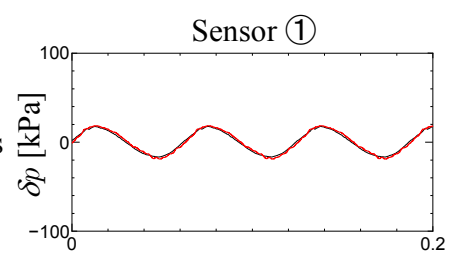

(ii) $22 \mathrm{rp}$

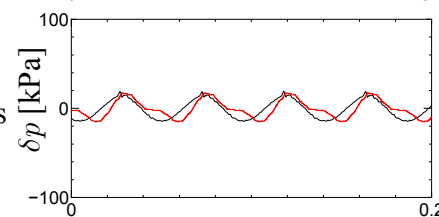

(iii)
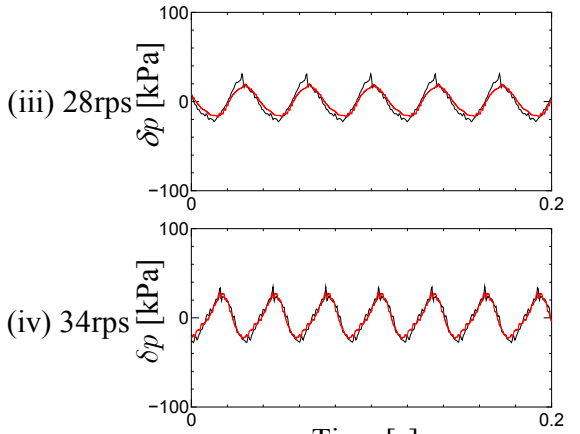

_ : Numerical results
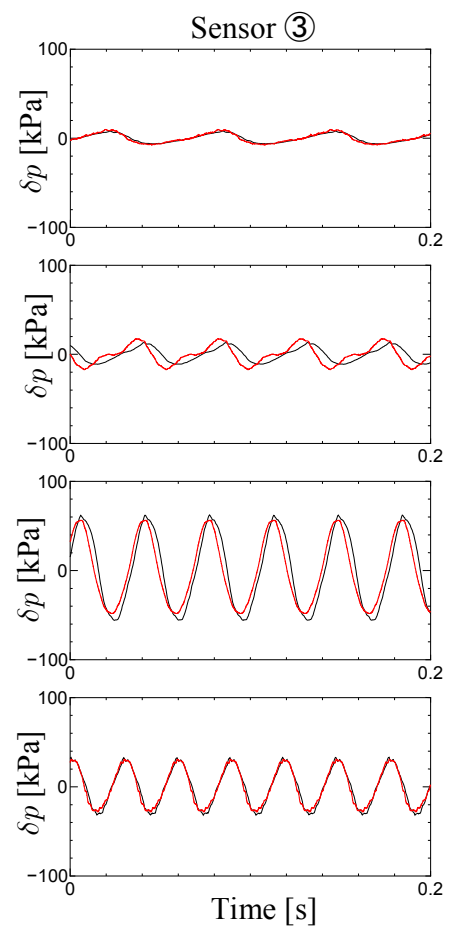

Fig. 6 These figures show the time-series waveform in the case of the gas-phase flow. The black lines show the experimental results, and the red lines show the numerical results. The numerical results agree well with the experimental results. When the revolution speed of the compressor is $28 \mathrm{rps}$, the resonance is generated.

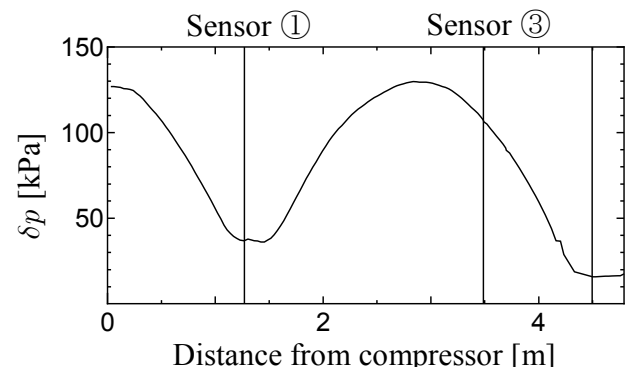

Fig. 7 This figure shows the distribution of the pressure amplitude distribution by the calculation in the case of (iii) 28rps. The left end is the compressor and the right end is the superior end of the 400 cc tank. The standing wave is generated as the compressor is the fixed end and the inferior end of the $400 \mathrm{cc}$ tank is the free end. 


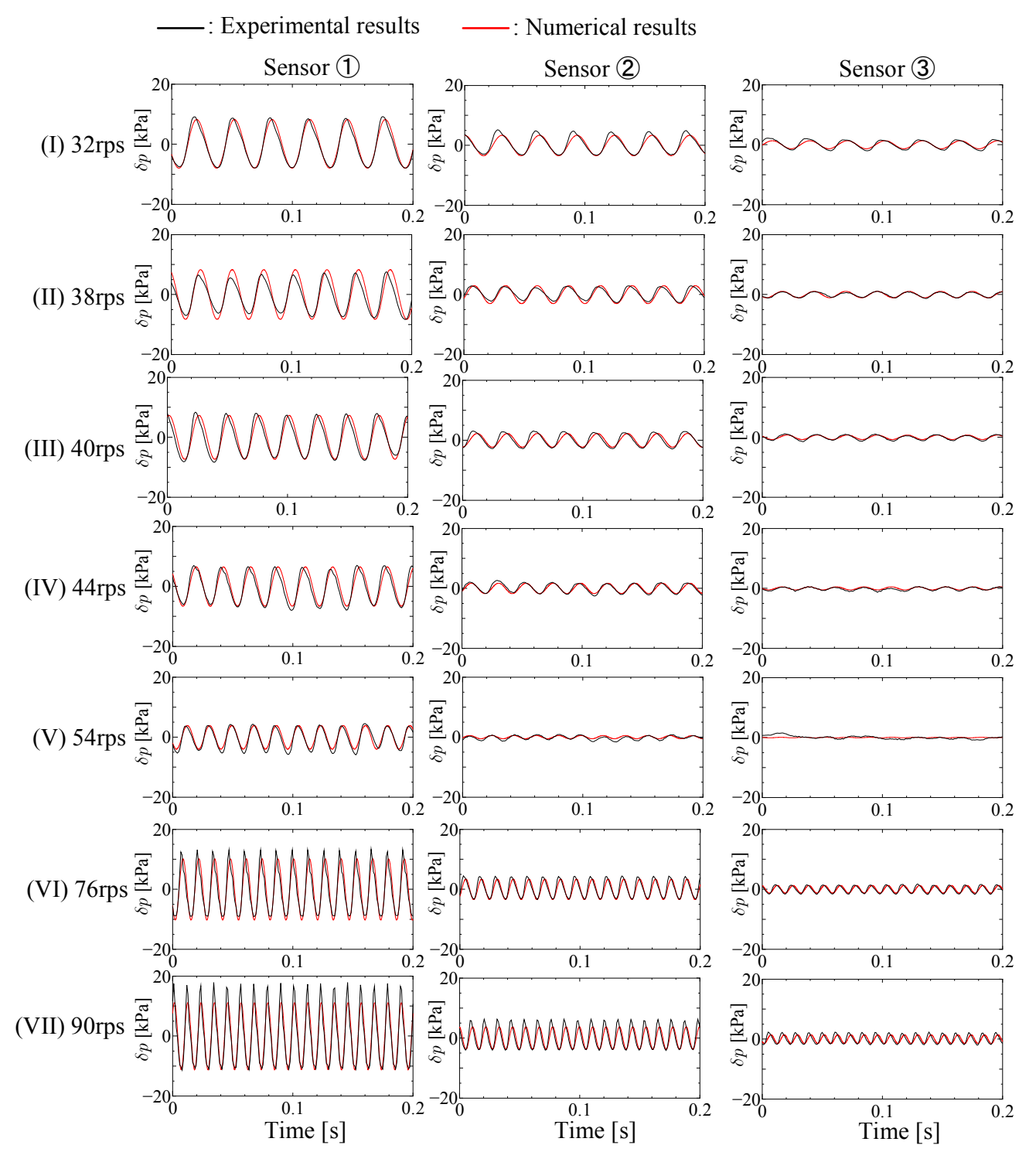

Fig. 8 These figures show the time-series waveform in the case of the two-phase flow. The black lines show the experimental results, and the red lines show the numerical results. The numerical results agree well with the experimental results in each condition. Then, the proposed model is valid for the pulsation phenomena in the one-component two-phase flow. The amplitude of the pressure wave is reduced with the distance from the compressor.

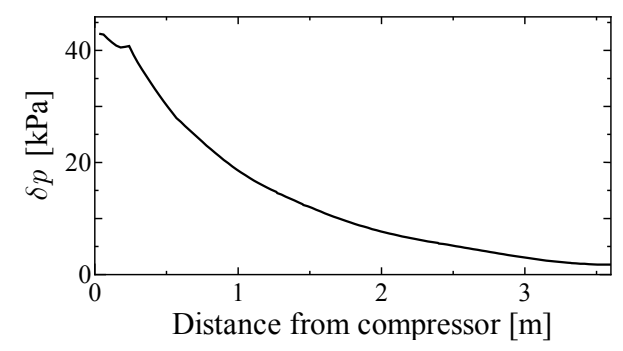

Fig. 9 This figure shows the distribution of the pressure amplitude distribution by the calculation in the case of the two-phase flow( (I) 32rps). The amplitude of the pressure wave is reduced with the distance from the compressor. The standing wave is not generated because the damping from the mass transfer. 


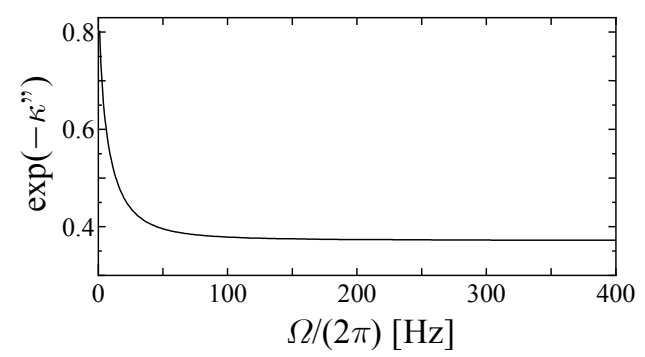

Fig. 10 This figure shows the distance attenuation of the pressure amplitude distribution to the variation of the frequency in the case I (32rps). The vertical axis shows the ratio of the pressure amplitude when the wave moves $1 \mathrm{~m}$. The amplitude of the pressure wave is reduced with the increase of the frequency.

振幅が他の条件より小さくなっているが，これは条件(IV)においてボイド率が最も小さいために音速 $a$ が小さく なり，音響インピーダンス $\rho_{m} a$ が小さくなるためと考えられる. 本モデルでは, 緩和時間 $\tau_{d}$ を与えるだけで各条 件，各測定位置とも実験結果の振幅と解析結果の振幅は非常によく一致しており，提案したモデルが妥当である ことが分かる.

図 9 は条件(I)の場合の解析による圧力振幅分布を示しているが, 図 7 の気相単体の場合とは異なり, 圧縮機か ら離れるほど振幅が減衰する分布となる．他の条件においても同様な分布となっているが，これは減衰が大きい ため定在波は発生せず，進行波のみの圧力波になっていると考えられる．管摩擦による非線形基礎支持減衰を省 いて解析を行ったところ，図 8，9 の結果にはほとんど影響を与えず，二相流の圧力波の減衰は，相変化時の質量 輸送の影響を考慮した結合ばねと結合減衰の影響が大きくなっていることが分かる．以上より，気相単相の場合 は管摩擦による減衰が支配的であるが，一成分二相流の場合は質量輸送による減衰が支配的となり，気相単相と 比較して減衰は大きくなる．これは，2・1 節で説明したように，一成分気液二相流では質量輸送の影響で圧力変 動がヒステリシスループを描き，エネルギー損失が生じるためである. この質量輸送によるエネルギー損失の方 が管摩擦によるエネルギー損失よりも大きいため, 一成分二相流において質量輸送による減衰が支配的になる. また, 質量輸送の減衰に対する振動数の影響を確認するために, 図 10 に, 条件(I)の物性值を用いて, 加振振動数 $\Omega /(2 \pi)$ を変化させたときの $\exp \left(-\kappa^{\prime \prime}\right)$ を示す. 式(40)から, $\exp \left(-\kappa^{\prime \prime}\right)$ は圧力波が $1[\mathrm{~m}]$ 進行したときの振幅の変化 率を表している. 図 10 より, 振動数が増加するほど $\exp \left(-\kappa^{\prime \prime}\right)$ は小さくなり, 圧力波の振幅は速く減衰する（距 離減衰が大きくなる). また, 振動数が大きくなると振幅の変化率は一定の值に収束していることが分かる.

以上より，本報で提案した集中系モデルは，緩和時間 $\tau_{d}$ を与えるだけで質量輸送による結合ばねと結合減衰の 影響を各条件とも再現できており，一成分気液二相流中の圧力波現象に対して有効なモデル化手法である.

\section{4. 結語}

円筒管内の一成分二相流中の圧力波現象に対寸る実用的な数值解析の実現を目指して，気相の圧縮性と相変化 時の質量輸送の影響を考慮した結合ばねと結合減衰，管摩擦の影響を考慮した非線形基礎支持減衰，および流体 の質量で構成される集中系モデルを提案した。このモデルの要点は, 質量輸送によるヒステリシス特性を結合は ねと結合減衰で表したことにある. そして, 空調機を改造した気液二相流中の圧力波測定実験を行い, 実験結果 と集中系モデルによる解析結果を比較したところ, 単相流, 二相流の両方の場合で定量的によく一致する結果が 得られた．特に，相変化時の緩和時間を決めることで，二相流中圧力波の質量輸送による結合ばねと結合減衰の 影響を精度良く再現できている，以上のように，本報で提案した集中系モデルは簡易なモデルであるにもかかわ らず高精度の計算結果を得ることが可能であり, 一成分気液二相流中の圧力波現象に対して非常に有効なモデル 化手法であるといえる. 


\section{文献}

赤川浩爾, 藤井照重, 伊藤裕, 杉山誠, 山口敏明, 福原一也, 気液二相流の衝撃現象に関する研究 (第 3 報, 気泡流 領域における圧力応答波形について），日本機械学会論文集 B 編, Vol.48, No.428 (1982), pp.767-774.

赤川浩爾, 藤井照重, 竹中信幸, 坪倉定雄, 平岡洋一, 小林純, 一成分気泡流中の水撃現象に関寸る研究（第 1 報, 圧力応答波形の実験結果），日本機械学会論文集 B 編, Vol.52, No.476 (1986), pp.1865-1871.

藤井照重, 赤川浩爾, 気泡流中の水撃現象の解析（第 2 報, 1 成分中の圧力応答波形），日本機械学会論文集 B 編, Vol.52, No.475 (1986), pp.1222-1227.

Idsinga, W., Todreas, N. and Bowring, R., An assessment of two-phase pressure drop correlations for stream-water systems, International Journal of Multiphase Flow, Vol. 3 (1977), pp. 401-423.

石川諭, 近藤孝広, 松崎健一郎, 集中系モデルによる非線形圧力波の解析（第 1 報, 解析モデルの提案とその妥当 性の検証），日本機械学会論文集 C 編, Vol.75, No.753 (2009), pp.1436-1443.

石川諭, 近藤孝広, 松崎健一郎, 集中系モデルによる非線形圧力波の解析（第 2 報, 分岐要素のモデル化とその妥 当性の検証），日本機械学会論文集 C 編, Vol.76, No.761 (2010a), pp.11-19.

石川諭, 近藤孝広, 松崎健一郎, 集中系モデルによる非線形圧力波の解析（第 3 報, 急拡大・急縮小要素のモデル 化），日本機械学会論文集 C 編, Vol.76, No.764 (2010b), pp.800-808.

松井剛一, 杉原正則, 有本卓, 気液せん列系の圧力伝ぱ特性（第 1 報，ステップ応答），日本機械学会論文集 B 編， Vol.45, No.391 (1979), pp.331-338.

森康夫, 土方邦夫, 河田治男, 微粒子を含む気体の音速（第 1 報, 静止気体中の音速の理論的研究）, 日本機械学 会論文集, 第 2 部, Vol.37, No.295 (1971), pp.546-555.

日本機械学会編，気液二相流技術ハンドブック(1989), p.124.

\section{References}

Akagawa, K., Fujii, T., Ito, Y., Sugiyama, M., Yamaguchi, T. and Fukuhara, K., Studies on shock phenomena in two-phase flow: 3rd Report, pressure propagation in bubbly flow region, Transactions of the Japan Society of Mechanical Engineers, Series B, Vol.48, No.428 (1982), pp.767-774 (in Japanese) .

Akagawa, K., Fujii, T., Takenaka, N., Tsubokura, S., Hiraoka, Y. and Kobayashi, J., Shock phenomena in a one-component two-phase bubbly flow : 1st Report, Experimental results on transient pressure profiles, Transactions of the Japan Society of Mechanical Engineers, Series B, Vol.52, No.476 (1986), pp.1865-1871 (in Japanese) .

Fujii, T. and Akagawa, K., Analysis of water hammering in bubbly flows: 2nd Report, Transient pressure profiles in one-component flows, Transactions of the Japan Society of Mechanical Engineers, Series B, Vol.52, No.475 (1986), pp.1222-1227 (in Japanese) .

Idsinga, W., Todreas, N. and Bowring, R., An assessment of two-phase pressure drop correlations for stream-water systems, International Journal of Multiphase Flow, Vol. 3 (1977), pp. 401-423.

Ishikawa, S., Kondou, T. and Matsuzaki, K., Nonlinear pressure wave analysis by concentrated mass model: 1st Report, Suggestion and validity verification of analytic model, Transactions of the Japan Society of Mechanical Engineers, Series C, Vol.75, No.753 (2009), pp.1436-1443 (in Japanese) .

Ishikawa, S., Kondou, T. and Matsuzaki, K., Nonlinear pressure wave analysis by concentrated mass model: 2nd Report, Modeling and validity verification of branch element, Transactions of the Japan Society of Mechanical Engineers, Series C, Vol.76, No.761 (2010a), pp.11-19 (in Japanese) .

Ishikawa, S., Kondou, T. and Matsuzaki, K., Nonlinear pressure wave analysis by concentrated mass model: 3rd Report, Modeling of enlargement and contraction element, Transactions of the Japan Society of Mechanical Engineers, Series C, Vol.76, No.764 (2010b), pp.800-808 (in Japanese).

Matsui, G., Sugihara, M. and Arimoto, S., Propagation characteristics of pressure wave through gas-liquid plug-train system: 1st Report, Step response, Transactions of the Japan Society of Mechanical Engineers, Series B, Vol.45, No.391 (1979), pp.331-338 (in Japanese) .

Mori, Y., Hijikata, K. and Kawada, H., Sound velocity in gas with particles: 1st Report, Theoretical study of sound velocity in stationary gas, Transactions of the Japan Society of Mechanical Engineers, Vol.37, No.295 (1971), pp.546-555 (in Japanese) .

The Japan Society of Mechanical Engineers ed., Handbook of Gas-Liquid Two-Phase Flow Technology (1989), p.124 (in Japanese). 